\title{
ODOS PAŽEIDIMAI SERGANT SARKOIDOZE: GENETINIAI IR IMUNINIAI DETERMINANTAI
}

\author{
Agnė Bartkevičiūtè1, Danielius Serapinas ${ }^{2,3}$ \\ ${ }^{1}$ Vilniaus universiteto Medicinos fakultetas, ${ }^{2}$ Lietuvos sveikatos mokslu universiteto \\ Medicinos akademijos Šeimos medicinos klinika, ${ }^{3}$ Mykolo Romerio universitetas
}

\author{
Raktažodžiai: odos sarkoidozè, granulomos, genetinè \\ rizika.
}

\begin{abstract}
Santrauka
Dažniausias sarkoidozės klinikinis požymis - plaučių pažeidimas, tačiau netgi 25 proc. ligos atvejų būna pažeista oda. Odos pažeidimai būna heterogeniniai. Jų pobūdis įvairus: tai ir mazginè eritema, žiedinè eritema, žvyninis, angiolupoidinis pažeidimai. Tai reikalauja kruopščios diferenciacijos nuo kitų odos ligų: žvynelinès, atopinio dermatito, odos pokyčių sergant reumatu. Jau yra nustatyti genai, susiję su sarkoidozès atsiradimu, taip pat pastebèta, kad skirtingos genų variacijos lemia skirtingą ligos išraišką. Apie 10 proc. visų sarkoidozès atvejų yra šeiminiai. Tyrimai rodo HLA antigenų ryši su sarkoidoze bei kandidatai SERPINB1, FABP4, S100A8, HBEGF, IL7R, LRIG1, PTPN23, DPM2, NUP214BTNL2, CCR2 ir ACE genų vaidmenį, kurie svarbūs antigeno pateikime, citokinų atsakui bei ląstelių tarpusavio sąveikai.

Svarbu, kad ateityje būtų toliau plètojami tyrimai, ypač siekiant išsiaiškinti genų-aplinkos ir genų tarpusavio sąveikas, kurios gali turèti įtakos sarkoidozès klinikai.
\end{abstract}

\section{Ivadas}

Sarkoizodè - tai létinè granuliominè nežinomos kilmès liga, kuri pasireiškia granulomų be kazeozinès nekrozès formavimusi paveiktuose organuose. Iš pradžių sarkoidozė buvo apibūdinama kaip odos liga, tačiau dabar žinoma, kad ji gali paveikti praktiškai bet kurị organą, o plautinis pažeidimas būna visada [1-3]. Manoma, kad esminè patofiziologijos priežastis - nenormalus imuninis atsakas ị aplinkos ar mikroorganizmų antigenus esant genetinei predispozicijai. Sarkoidozė gali turèti gerybinę asimptomatinę eigą ar sunkią, kai prarandamos pažeistų organų funkcijos. Staigiai prasi- dẻjęs karščiavimas, abipusė plaučių vartų limfadenopatija ir mazgine eritema su ar be kulkšnies sąnario uždegimu leidžia manyti esant geresnès prognozès eigą.

Genų svarbą ligai išsivystyti rodo dažnesnis tarp monozigotinių dvynių ligos konkordantiškumas nei tarp dizigotinių, 5-16\% pacientų turi sergančių šeimos narių [4-5], yra esminių skirtumų tarp ligos pasireiškimo ir klinikinių ypatybiu skirtingose geografinèse zonose ir rasèse. Sarkoidozę lemia ne vienas genas ar imuninio atsako defektas. Egzistuoja daugybė genų, kurių pavienè įtaka gana maža, ir tik turimi keli genai, būtini ligai pasireikšti [6-7]. Genai tikriausiai apsprendžia ligos eigą ir prognozę.

Paprastai genetinès studijos, tiriančios sarkoidozę, remiasi kandidatinio geno atvejo kontrolès tyrimais. Kandidatinis genas nustatomas remiantis esamomis biologinemis hipotezėmis, tada tiriamas jo pasireiškimas tarp sergančiujų ir sveikujųu. Jei neaišku, kokie pagrindiniai defektai lemia ligą, minètas tyrimo metodas gali iš dalies paaiškinti genetinę ligos prigimtį. Vis dẻlto šiuo metodu yra atrasta nemažai asociacijų, daugiausia su aleliais, esančiais HLA regione [8-9].

Darbo tikslas - aptarti retos ligos - sarkoidozès manifestacijos odoje ypatumus bei ligos genetinius ir imuninius aspektus.

\section{Tyrimo metodika}

Mokslinių straipsnių PuBMed duomenų bazèje apžvalga su raktiniais žodžiais sarkoidozé, odos forma, patogenezé, genetika.

\section{Rezultatai ir jų aptarimas}

4 dažniausios odos sarkoidozės formos. Nors sarkoidozė dažniausiai pasireiškia plaučių pažeidimu, yra bent 4 odos pažeidimo formos, aptinkamas 25 proc. sergančiųu sarkoidoze. Odoje sarkoidozė gali pasireikšti mazgine eritima (1 pav.), angiolupoidiniais (2 pav.), žvyniniais (3 pav.) odos pažeidimais bei žiedine eritema (4 pav.) $[1,10]$. Nustatant diagozę be galo svarbi ligos anamnezè, genealogija bei klinikinis ištyrimas. Odos sarkoidozès formos diagnozei 
patvirtinti svarbi diferencinė diagnostika su žvyneline, reumatinėmis ligomis, rože bei egzema (1-4 pav.).

HLA klasės antigenai. Pastaraisiais metais daug sąsajų aptikta tarp odos sarkoidozès ir HLA sistemos genų (5 pav.), ypač DRB1 ir DQB1. Tokie genai kaip BTNL2, CCR2 ir ACE yra svarbūs pateikiant antigeną, citokinų atsakui bei ląstelių tarpusavo signalams [9,11-13] .

Yra studijų, aptikusių padidejjusią sarkoidoze sergančių pacientų onkogeno Gli-1 ekspresiją. Svarbūs genai kandidatai SERPINB1, FABP4, S100A8, HBEGF, IL7R, LRIG1, PTPN23, DPM2 ir NUP214 buvo aptikti atskirose studijose, tačiau atliekant viso genomo palyginamąsias studijas patvirtinta HLA ir BTNL2 genų itaka odos sarkoidozei. O ANXA11 ir RAB23 genai taip pat buvo reikšmingi, nes susiję su priešbakterine apsauga [1, 14-15].

Stipriausias ryšys šiuo metu nustatytas su HLA II klasès

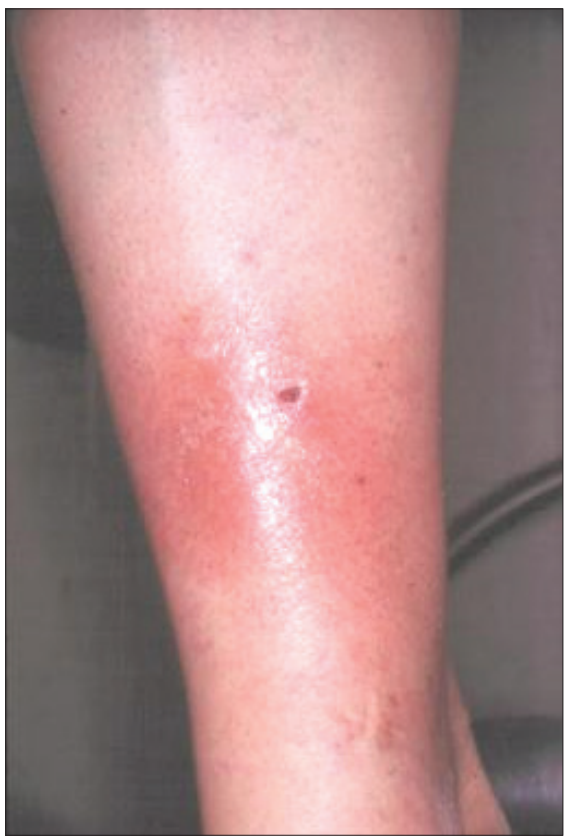

1 pav. Mazginė eritema. Šaltinis - Medscape.

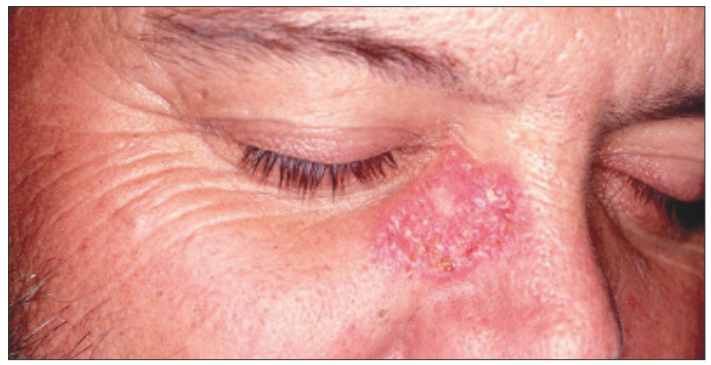

2 pav. Angiolupoidiniai pažeidimai (Lupus pernio). Šaltinis - Medscape. tipo DRB1 aleliais [9, 16-18]. Tačiau stipriai varijuojanti sankibos pusiausvyros stoka trukdo nusakyti, kurie genai svarbiausi lemiant ligą, nes tame pačiame regione yra ne HLA genų, kurie atsakingi už imuninį atsaką. Pastebèta, kad tarp skirtingų etninių grupių yra tam tikras DRB1 alelių šabloniškumas: DRB1*01,04 mažina sarkoidozès riziką, o $\mathrm{DRB}^{*} 03,11,12,14,15$ didina. İdomu, kad tarp afroamerikiečių stipriausias ryšys nustatomas su HLA-DQB1, o ne DRB1 [17-18].

Eilè vėlesnių tyrimų, naudojančių labiau specifiškus HLA tyrimo metodus ir griežtesnius sarkoidozès ligos kriterijus, patvirtino esant ryšius su Lofgren'o sindromu, kuris, nors ir kliniškai panašus, tačiau genetiškai skirtinga sarkoidozès išraiška. Suskirstyti sergančius sarkoidoze su Lofgren'o sindromu galima ne tik pagal ligos skirtingas išraiškas, bet ir

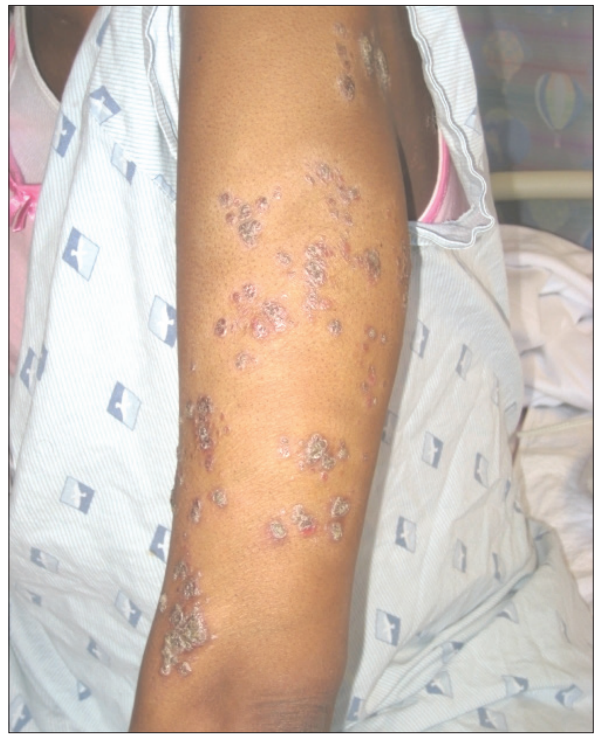

3 pav. Žvyniniai pažeidimai sergant sarkoidoze. Šaltinis - Medscape.

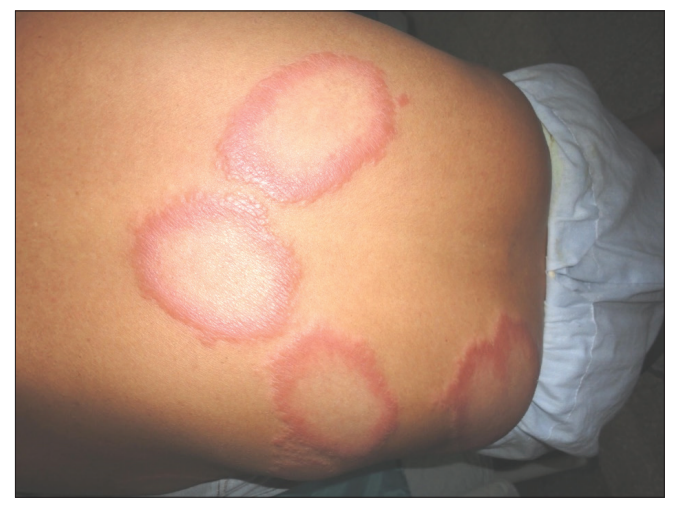

4 pav. Žiedinè eritema. Šaltinis - Medscape. 


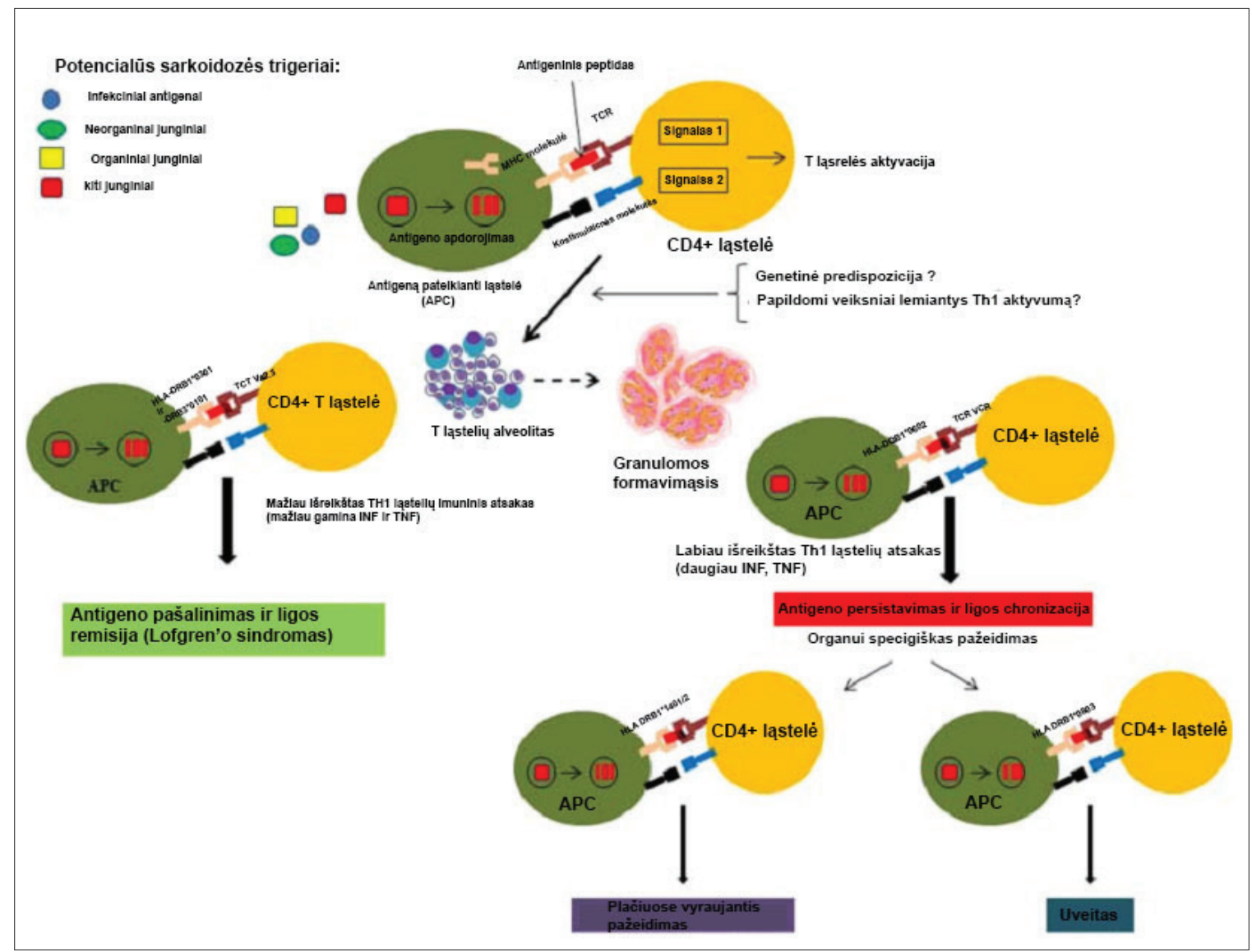

5 pav. Sarkoidozės patogenezè. Paveikslo aprašymas: sarkoidozė atsiranda daugiausia kaip Th1 ląstelių imuninis atsakas. Th1 ląstelès po antigeno pateikimo aktyvuojamos kaip makrofagai ar dentritinès ląstelès. Prieš tai antigenas endosomose/ lizosomose suvirškinamas iki mažesnių fragmentų, ir tai transportuojama ant MHC molekulių (pagrindinio audinio suderinamumo komplekso). MHC molekulè tuomet prisijungia prie TCR (T ląstelių receptorių) ir inicijuojamas signalas 1. Kad įvyktų T ląstelių aktyvacija taip pat būtinos kostimuliacinès molekulès (pvz., CD28), kurios jungiasi su CD80 ir CD86, esančių ant APC (2 signalas). T ląstelès toliau koordinuoja imuninị atsaką, siekia pašalinti antigeną ar jị izoliuoti formuodamos granulomas. I̦vairūs veiksniai kaip HLA ir ne HLA aleliai, gali alteruoti ši procesą. HLA-DRB1*0301 ir DRB3*0101 tikriausiai lemia, kad imuninis atsakas visiškai pašalina antigenus ir pasiekiama ligos remisija. Esant HLADQB1*0602, -DRB1*12, -DRB1*14 skatina per didelị T ląstelių atsaką (didejja IFN- $\gamma$, TNF- $\alpha$ ir mažeja TGF- $\beta$ ). Tuomet prasideda nuolatinis granulomų formavimasis, sintetinimai profibrotiniai citokinai, liga tampa chronine. Ar granuloma išnyks, persistuos ar didès, priklauso taip pat nuo eilès faktorių: apoptozès reguliacijos, Th17 ląstelių atsako ir kitų veiksnių.

pagal alelio DRB1*01 turèjimą. Pastebèta, kad ligos rezoliucijos stadija (kai sergama ne ilgiau kaip $2 \mathrm{~m}$.) pasiekiama $95 \%$, kai pacientas turi DRB $1 * 03$, o neturintiems $-49 \%$. İdomu, kad ligos paūmèjimai sausio, balandžio ir gegužès mènesiais pastebèti tik pacientams, turintiems DRB1*03. Tad gali būti, kad Lofgren'o sindromui įtakos turi sezoniški antigenai. Mechanizmas, kaip DRB1*03 veikia sarkoidozę, nèra žinomas, tačiau pastėbèta, kad šie pacientai turi mažiau išryškejjusị ląstelių TH1 atsaką ir mažesnius kiekius IFN gama ir TNF alfa [19-20].
Kiti genų aleliai (ne HLA) taip pat turi didelès reikšmès Lofgren'o sindromui išsivystyti. Tam tikros polimorfizmo kombinacijos gene CCR2 (CC chemokino receptorius 2) didina Lofgren'o sindromo riziką nepaisant, ar yra DRB1*03. Tai buvo patvirtinta dviejose nepriklausomose populiacijose, tačiau Vokietijoje atliktoje atvejo-kontrolès studijoje negautas toks rezultatas. Jų duomenimis, imlumą sindromui didina genas esantis toje pačioje chromosomoje netoli CCR2. Išlieka neaišku, kodèl atsiranda tokie prieštaringi rezultatai: tai galëjo atsitikti dèl nevienodų (netikslių) atvejų aprašymų, 
variacijų, esančių dèl etniškumo, ar kitų priežasčių.

Dar vienas stiprus ryšys rastas Lofgren'o sindromo su audinių suderinamumo komplekso (MHC2TA) geno polimorfizmu (lemiančiu MHC molekulès ekspresiją). Šis mutacijos ryšys taip pat randamas nepaisant, ar yra randama DRB1*03. Dèl to manoma, kad Lofgren'o sindromas yra kitos kilmès nei pati sarkoidozè [21,22].

Siekiant išsiaiškinti, ar esantys nesuderinami studijų duomenys yra dèl tarpetninių ypatybių, buvo ištirtos trys nepriklausomos pacientų imtys (iš Jungtinès Karalystès, Nyderlandų ir Japonijos). Kaip ir tikètasi, populiacijose sarkoidozès išraiškos labai skyrèsi, tačiau ir nepaisant to, išsiaiškinta, kad HLA ryšiai su liga buvo panašūs, kaip ir studijose su specifine etnine grupe: DRB $1 * 01$ susijęs su mažesne rizika, DRB1*12 ir DRB1*1401/2 su didesne rizika (dominuojant plaučių pažeidimui), o DRB1*0803 lemia didesnę riziką tik Japonijos populiacijai (ypač esant sarkoidozès kilmès uveitui). DRB*0301 ir DQB1*0201 veikia kaip apsauga nuo ligos britų populiacijoje, bet atvirkščiai veikia japonų populiaciją. Kitoje studijoje rastas ryšys tarp HLA-DRB $1 * 04$ kaukaziečių kilmès populiacijoje ir sarkoidoze su Herfordt'o sindromu (kombinacija uveito, galvinių nervų paralyžiaus, seilių liaukų padidejjimo ir karščiavimo) [9, 23].

Per pastaruosius metus, viso genomo asociacijos tyrimai (GWAS - genome wide association study) sukèlè revoliuciją žmogaus genetikoje ir atrado daug genomo vietų, kurios lemia sudėtingų ligų imlumą. Vienoje senesnèje studijoje tarp 55 sergančių sibsų šeimų buvo ieškoma polimorfizmo MHC koduojamame regione ir šalia jo. Neparametriniu kriterijumi rastas patikimas ryšys su 3 klasès genų grupès lokusu D6S1666. Studijos autoriai pakartojo panašius rezultatus naudodami mikrosatelininius markerius. Kiti autoriai afroamerikiečių populiacijoje rado ryšį su D5S2500. Apibendrinus nustatyta, kad aleliai chromosomoje 5p15.2 didina ligos riziką, 5q11.2 mažina $[8,10]$.

Išsamesnis sekvanavimas $\mathrm{MHC}$ regione nustaté naujo tipo patologiją sukelianti variantą: ydingas splaisingas penktame egzone, gene, koduojančiame panašų i i butirofiliną baltymą (BTNL2). Manoma, kad šis baltymas veikia neigiamai kostimuliacinius receptorius. Jo strūktūra turi panašumų i CD80 ir CD86 molekules. Defektyvus BTNL2 gali lemti per didelị T limfocitų aktyvumą, o tai tiktų sarkoidozès patofiziologijai. İdomu, kad šis pakitimas randamas nepasaint HLA II klasès alelių, nors esama ryškios sankibos pusiausvyros stokos su HLA-DRB1. Tačiau tiriant ligas, tokias kaip opinis kolitas, išsètinè sklerozè, pirmo tipo cukrinis diabetas, reumatoidinis artritas ir kitos, vienas BTNL2 variantas rs2076530 A yra priklausomas nuo HTL-DRB1 alelių buvimo. Sunku nusakyti priežastingumo ryšius, kai svarbūs genai yra šalia vienas kito, tad išsamesni HLA tyrimai reikalingi.
Viename pirmujų GWAS tyrimų atlikta pilna genomo paieška naudojant 440000 vieno nukleotido polimorfizmus (angl. Single nucleotide polymorphism SNP). Tiriant vokiečių populiaciją (499 sergančiujų ir 490 sveikų), stipriausią ryši rado su aneksino 1 genu (ANXA11) chromosoje 10q22.3. Tokie rezultatai buvo ir kitose nepriklausome studijose, kuriose imtys sudarytos iš kitų Europos šalių, Afrikos, ir Amerikos segančiujų. ANXA11 genas atsakingas už kalcio kanalų reguliavimą, ląstelių vezikulių judejimą, apoptozę $[9,16]$. Patvirtinta, kad jis dalyvauja kai kurių autoimuninių ligų patogenezèje (kaip reumatoidinis artritas), lemdamas padidejjusị antikūnių skaičių. Koks jo vaidmuo sarkoidozėje nèra tiksliai žinoma, manoma, kad nenormalus ANXA11 veikimas gali lemti pakitusią apoptozès pusiausvyrą tarp imuninių ląstelių.

Ieškant lemiamų ryšių genome su sarkoidoze su SNP markeriais, rastas ne vienas stiprus ryšys ịvairiose studijose. Tokie ryšiai rasti chromosomose $8 \mathrm{p} 12,5 \mathrm{p} 13,5 \mathrm{q} 31$, 12p13.31, 9q33.1, 6p12.1 [9,24]. Viena GWAS studija naudojo 1,3 mljn markerių ir rado naują lokusą 11q13.1 chromosomoje. Šis ryšys buvo rastas trijose skirtingose Europos populiacijose. Išsamesnè analizė rodo, kad tai galètų būti genas CCDC88B, nors jo vaidmuo dar nežinomas. Taip pat nèra žinoma, ar kitose, ne Europos, populiacijose būtų irgi rastas ryšys. Tačiau jau žinoma, kad jis predisponuoja kitas ligas, tokias kaip Krono liga, pirminè biliarinè cirozè, psoriazè. Kita nauja studija naudojo 6 mljn markerių, ir be jau minètų atradimų, nustate naują lokusą NOTCH4. NOTCH baltymų šeima koduoja baltymus, kurie kontroliuoja ląstelès diferenciaciją ir T ląstelių atsaką [9]. Toje pačioje studijoje nustatyta, kad šie ryšiai irgi skiriasi tarp įvarių šalių populiacijų.

\section{Išvados}

1. Šiuolaikinès žinios apie odos sarkoidozę leidžia manyti, kad esama ne vieno genetinio trigerio.

2. Antigenus CD4 T ląstelèms perduoda tam tikros HLA klasès molekulès.

3. Trigerinių aplinkos veiksnių paieška gali lemti geresnį ligos supratimą ir geresnių gydymo metodų suradimą. Ligos gydymas turètų būti personalizuotas dèl daugybès esančių pasireiškimo formų.

\section{Literatūra}

1. Sepideh Shahkaramil and Nima Rezaei1,2. Genetic predisposition to cutaneous sarcoidosis. Acta Medica Iranica 2012; 50:721-722.

2. Spagnolo P, Grunewald J. Recent advances in the genetics of sarcoidosis. J Med Genet 2013;50:290-297

https://doi.org/10.1136/jmedgenet-2013-101532 
3. Spagnolo P, Luppi F, Roversi P, Cerri S, Fabbri LM, Richeldi L. Sarcoidosis: challenging diagnostic aspects of an old disease. Am J Med 2012;125:118-25.

https://doi.org/10.1016/j.amjmed.2011.06.003

4. Grunewald J. HLA associations and Löfgren's syndrome.Expert Rev Clin Immunol 2012;8:55-62.

https://doi.org/10.1586/eci.11.76

5. Sverrild A, Backer V, Kyvik KO, Kaprio J, Milman N, Svendsen $\mathrm{CB}$, Thomsen SF. Heredity in sarcoidosis: a registry-based twin study.Thorax 2008;63:894-6.

https://doi.org/10.1136/thx.2007.094060

6. Hosoda Y, Yamaguchi M, Hiraga Y. Global epidemiology of sarcoidosis. What story do prevalence and incidence tell us?Clin Chest Med1997;18:681-94.

https://doi.org/10.1016/S0272-5231(05)70412-3

7. Grunewald J. Role of genetics in susceptibility and outcome of sarcoidosis. Semin Respir Crit Care Med2010;31:380-9.

https://doi.org/10.1055/s-0030-1262206

8. Spagnolo P, du Bois RM. Genetics of sarcoidosis.Clin Dermatol 2007;25:242-9.

https://doi.org/10.1016/j.clindermatol.2007.03.001

9. Grunewald J, Eklund A, Olerup O. Human leukocyte antigen class I alleles and the disease course in sarcoidosis patients. Am J Respir Crit Care Med 2004;169:696-702. https://doi.org/10.1164/rccm.200303-459OC

10. Spagnolo P, Richeldi L, du Bois RM. Environmental triggers and susceptibility factors in idiopathic granulomatous diseases. Semin Respir Crit Care Med 2008;29:610-19.

https://doi.org/10.1055/s-0028-1101271

11. Moller DR, Chen ES. Genetic basis of remitting sarcoidosis: triumph of the trimolecular complex? Am J Respir Cell Mol Biol2002;27:391-5.

https://doi.org/10.1165/rcmb.2002-0164PS

12. Noor A, Knox KS. Immunopathogenesis of sarcoidosis.Clin Dermatol 2007;25:250-8.

https://doi.org/10.1016/j.clindermatol.2007.03.002

13. Ziegenhagen MW, Benner UK, Zissel G, Zabel P, Schlaak M, Müller-Quernheim J. Sarcoidosis: TNF-alpha release from alveolar macrophages and serum level of sIL-2R are prognostic markers.Am J Respir Crit Care Med 1997;156:1586-92.

https://doi.org/10.1164/ajrccm.156.5.97-02050

14. Iannuzzi MC, Rybicki BA. Genetics of sarcoidosis: candidate genes and genome scans.Proc Am Thorac Soc 2007;4:108-16. https://doi.org/10.1513/pats.200607-141JG

15. Müller-Quernheim J, Schürmann M, Hofmann S, Gaede KI, Fischer A, Prasse A, Zissel G, Schreiber S.Clin Chest Med2008;29:391-414.

https://doi.org/10.1016/j.ccm.2008.03.007

16. Grunewald J, Eklund A. Löfgren's syndrome. Human leukocyte antigen strongly influences the disease course.Am J Respir Crit Care Med2009;179:307-12.

https://doi.org/10.1164/rccm.200807-1082OC

17. Idali F, Wikén M, Wahlström J, Mellstedt H, Eklund A, Rabbani H, Grunewald J. Reduced Th1 response in the lungs of HLADRB1*0301 patients with pulmonary sarcoidosis.Eur Respir J 2006;27:451-9.

https://doi.org/10.1183/09031936.06.00067105

18. Spagnolo P, Renzoni EA, Wells AU, Sato H, Grutters JC, Sestini P, Abdallah A, Gramiccioni E, Ruven HJ, du Bois RM, Welsh KI. C-C chemokine receptor 2 and sarcoidosis: association with Löfgren's syndrome.Am J Respir Crit Care Med 2003;68:1162-6.

https://doi.org/10.1164/rccm.200303-456OC

19. Spagnolo P, Sato H, Grunewald J, Brynedal B, Hillert J, Ma-á J, Wells AU, Eklund A, Welsh KI, du Bois RM. A common haplotype of the $\mathrm{C}-\mathrm{C}$ chemokine receptor 2 gene and HLADRB $1 * 0301$ are in dependent genetic risk factors for Löfgren's syndrome.J Intern Med 2008;264:433-41.

https://doi.org/10.1111/j.1365-2796.2008.01984.x

20. Valentonyte R, Hampe J, Croucher PJ, Müller-Quernheim J, Schwinger E, Schreiber S, Schürmann M. Study of C-C chemokine receptor 2 alleles in sarcoidosis, with emphasis on familybased analysis.Am J Respir Crit Care Med 2005;171:1136-41. https://doi.org/10.1164/rccm.200405-6580C

21. Grunewald J, Idali F, Kockum I, Seddighzadeh M, Nisell M, Eklund A, Padyukov L. MHC class II transactivator gene polymorphism in sarcoidosis: specific associations with Löfgreńs syndrome. Tissue Antigens 2010 76:96-101.

22. Sato H, Woodhead FA, Ahmad T, Grutters JC, Spagnolo P, van den Bosch JM, Maier LA, Newman LS, Nagai S, Izumi T, Wells AU, du Bois RM, Welsh KI. Sarcoidosis HLA class II genotyping distinguishes differences of clinical phenotype across ethnic groups. Hum Mol Genet 2010;19:4100-11. https://doi.org/10.1093/hmg/ddq325

23. Spagnolo P, Sato H, Marshall SE, Antoniou KM, Ahmad T, Wells AU, Ahad MA, Lightman S, du Bois RM, Welsh KI. Association between heat shock protein 70/ Hom genetic polymorphisms and uveitis in patients with sarcoidosis.Invest Ophthalmol Vis Sci 2007;48:3019-25.

https://doi.org/10.1167/iovs.06-1485

24. Darlington P, Tallstedt L, Padyukov L, Kockum I, Cederlund K, Eklund A, Grunewald J. 2011. HLA-DRB1* alleles and symptoms associated with Heerfordt's syndrome in Sarcoidosis.Eur Respir J 2011;38:1151-7. https://doi.org/10.1183/09031936.00025011

25. Hindorff LA, Sethupathy P, Junkins HA, Ramos EM, Mehta JP, Collins FS, Manolio TA. Potential etiologic and functional implications of genome-wide association loci for human diseases and traits.Proc Natl Acad Sci U S A 2009;106:9362-7. https://doi.org/10.1073/pnas.0903103106 


\section{SKIN MANIFESTATIONS OF SARCOIDOSIS: GENETIC AND IMUNOLOGIC DETERMINANTS}

\section{A.Bartkevičiūtè, D.Serapinas}

Key words: skin sarcoidosis, granulomas, genetic risk. Summary

Sarcoidosis most commonly involves lungs, however, dermatologic manifestation are seen in $25 \%$ of affected patients. Skin lesions usually are heterogenic. Cutaneous lesions can present with a variety of morphologies: nodular erythema, plaque-like, pdoriasiform, angiolupoid lesions. Tehrefore, the thorough differential diagnosis with other diseases such as psoriasis, atopic dermatitis, reumathic skin lesions, should be perfomed. There are already several genes defined that are responsible for the skin manifestations in sarcoidosis. Also, it has been reported that different gene variations lead to different disease manifestations. About $10 \%$ of all sarcoidosis cases are familial. Studies have shown that there is significant connection between HLA antigens and sarcoidosis as well as with SERPINB1, FABP4, S100A8, HBEGF, IL7R, LRIG1, PTPN23, DPM2, NUP214BTNL2, CCR2 and ACE genes, which are important in antigen presentation, cytokine response and cell communication. It is important, to continue studies in this area, especially trying to define genetic and environmental factors and their interaction that may contribute to sarcoidosis manifestation.

Correspondence to: dserapinas@gmail.com

Gauta 2018-05-18 